\title{
Factors associated with burnout syndrome in medical residents of a university hospital
}

Pedro Alves da Cruz Gouveia ${ }^{1 *}$, Maria Hosana Chaves Ribeiro Neta ${ }^{1}$, Carlos Alberto de Moura Aschoff $^{2}$, Doris Pires Gomes ${ }^{2}$, Nadine Anita Fonseca da Silva ${ }^{2}$, Helton Alexsandro Firmino Cavalcanti ${ }^{3}$

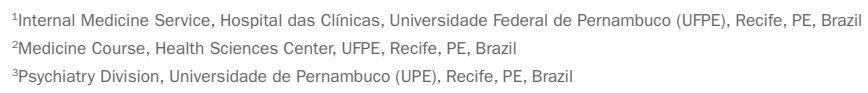

Study performed at Hospital das Clínicas of Universidade Federal de Pernambuco (HC-UFPE), Recife, PE, Brazil

Article received: $10 / 22 / 2016$ Accepted for publication: 11/20/2016

\section{*Correspondence:} Address: Av. Prof. Moraes Rego, 1.235, Cidade Universitária Recife, PE - Brazil Postal code: 50670-901 pedroalves@doctor.com

\section{SUMmARY}

Objective: To determine the prevalence of burnout syndrome among resident physicians of various specialties and to evaluate associated factors.

Method: The Maslach Burnout Inventory questionnaire and a sociodemographic questionnaire were used to evaluate factors associated with the syndrome. Burnout was defined as the association of high emotional exhaustion, depersonalization and low professional achievement. Multivariate analysis was performed after adjustment of the Poisson model with the identification of risk factors and calculation of prevalence ratios (PR). Of the 250 resident physicians registered with Hospital das Clínicas of Pernambuco, 129 participated in the study.

Results: In the three domains that characterize burnout syndrome, we found a low level of professional achievement in $94.6 \%$ of resident physicians interviewed, a high level of depersonalization in $31.8 \%$, and $59.7 \%$ with a high level of emotional exhaustion. The prevalence of burnout was $27.9 \%$. Having suffered a stressful event in the last six months (PR: 8.10; 95CI 1.2-57.2) and being a student of surgical specialty (PR: 1.99; 95CI 1.2-3.3) were independently associated with burnout.

Conclusion: The prevalence of burnout found in resident physicians is in accordance with previous Brazilian studies. Residents of surgical specialties and those who suffered some stressful event were identified as susceptible in this study. The early identification of risk factors is fundamental for the implementation of preventive measures against burnout syndrome.

Keywords: burnout, medical residency, medical education.

\section{INTRODUCTION}

The term burnout was coined by psychologist Herbert Freudenberger in 1974 in an article entitled "Staff Burnout," in which he discusses job dissatisfaction caused by professional stress. ${ }^{1}$ Although there is no standard definition for burnout, it is described as a state of physical and mental exhaustion from work when coping methods are insufficient. ${ }^{2}$ Burnout syndrome is defined as a triad composed of three domains: emotional exhaustion, depersonalization and decline in professional achievement. ${ }^{3}$

Emotional exhaustion reflects the stress dimension of burnout and encompasses feelings of hopelessness, loneliness, depression, anger, impatience, irritability, ten- sion, decreased empathy, a sense of lack of energy, and worry. Depersonalization is an attempt that a person makes to put distance between themselves and the recipients of the service, actively ignoring the qualities that make them unique individuals, motivating a sense of alienation and indifference towards others. This makes working with other people often unpleasant and unwanted. Low professional achievement or low job satisfaction, in turn, can be described as a feeling that very little has been achieved and what is accomplished is worthless. ${ }^{2,4}$

The consequences of burnout syndrome on health include: gastrointestinal disorders, prolonged flu symptoms, shortness of breath, hypertension, headache, insomnia, 
myalgia, pruritus, allergies, hair loss, sexual dysfunction, demotivation, difficulty concentrating and more. ${ }^{5}$ Also, there is a correlation between burnout and suicidal thinking. ${ }^{6}$ Therefore, this is a public health problem with disastrous consequences that must be prevented in the workplace.

Stressors that are associated with or may increase the possibility of burnout among physicians include: excessive demands that reduce the quality of care, long working hours, numerous work shifts, the need to deal with suffering and death, and more. ${ }^{7}$ In medical training, residency is a critical and very stressful period in which constant overloading and sleep deprivation are observed, as well as possibly fatigue and fear of making mistakes. ${ }^{8}$ It is a favorable period for the development of burnout syndrome, due to its duality of roles (learning and work) and strong pressure derived from preceptors, society and the residents themselves. ${ }^{9}$ Lack of autonomy, competitiveness, new expectations, inadequate support from supervisors and irregular work schedules are other problems of residency that correlate with burnout. ${ }^{10}$

The objective of our study was to determine the prevalence of burnout among resident physicians at Hospital das Clínicas - Universidade Federal de Pernambuco (HC-UFPE) and to evaluate its associated factors.

\section{Method}

This is a cross-sectional descriptive study carried out at the HC-UFPE in October and November 2015. The target population was residents enrolled in the medical residency program that year. Data collection was done through self-administered questionnaires, and confidentiality was maintained. All participants signed a free and informed consent form. There were 250 registered residents, of whom 129 participated in the survey. The total number of residents was not reached due to difficulty in approaching some residents in the following situations: vacation period, external rotation, working hours at the time of questionnaires, non-return of the questionnaires and lack of consent to participate in the survey.

Burnout syndrome was evaluated based on the Maslach Burnout Inventory (MBI), a version adapted to Brazilian Portuguese $\mathrm{e}^{11}$ and structured with 22 questions subdivided into the areas of emotional exhaustion, depersonalization and professional achievement. In order to classify the emotional exhaustion domain, we used the following scoring criteria: low ( $\leq 18$ points), moderate (19 to 26 points) and high ( $\geq 27$ points). The classification of the depersonalization domain was done according to the following score: low ( $\leq 6$ points), moderate (seven to 12 points) and high ( $\geq 13$ points). For the professional achievement domain, the classification was made according to the following criterion: low ( $\leq 33$ points), moderate (34 to 39 points) and high ( $\geq 40$ points). The criterion used in our study to define burnout syndrome was the presence of high values for the emotional exhaustion and depersonalization domains, combined with a low score for professional achievement. ${ }^{5,12}$

A sociodemographic questionnaire was also used to evaluate factors associated with burnout syndrome. Specialties considered as "surgical clinic" were: general surgery, orthopedics, urology, plastic surgery, surgery of the digestive system, vascular surgery, gynecology and obstetrics, ENT, and ophthalmology. The group named "other clinics" included internal medicine, pediatrics, dermatology, radiology, psychiatry, neurology, infectious diseases, nephrology, cardiology, oncology, endocrinology, rheumatology, gastroenterology, and family and community medicine. The following were considered "stressful events": personal or family-related health problems, mourning, separation, difficult relationship with boss/colleagues/ associates/patients, financial problems, relationship problems with family members. We considered regular physical activity as defined by the World Health Organization: over 150 weekly minutes of moderate activity (brisk walking, dancing, active participation in games and sports with children and walking with pets) or over 75 minutes of intense activity (cycling, aerobic exercises, fast swimming, sports and competitive games).

The data were analyzed using Statistical Package for Social Sciences - SPSS software version 13.0. In order to evaluate the personal and professional profile, habits, level of physical activity and living conditions of the residents participating in the study, percentages were calculated and the frequency distributions of the evaluated factors were constructed. Chi-square test was used to compare proportions.

To evaluate the factors associated (personal and professional profile and daily habits of residents) with burnout syndrome and its subdomains, a contingency table was constructed and the Chi-square test for independence was applied. In cases where the assumptions of the Chi-square test were not confirmed, Fisher's exact test was applied. All conclusions were taken considering the significance level of $5 \%$. Multivariate analysis for the factors associated with burnout was done by adjusting the Poisson model with robust variance, while factor significance was assessed using Wald statistic. For entry into the model, we considered the variables with $\mathrm{p}<0.2$ in the univariate analysis. To retain the variable in the final model, we calculated the prevalence ratios and considered $\mathrm{p}<0.05$. 
The research was performed after analysis and approval by the Ethics Committee of the Health Sciences Center of Universidade Federal de Pernambuco (CEP/ CCS/UFPE), in accordance with Resolution No. 466/2012 on "Research involving Human Beings" of the Ministry of Health, Opinion No. 49197615.2.0000.5208.

\section{Results}

In relation to the personal profile of the participants, we found that most are in the first or second year of residency (67.4\%), aged up to 28 years (52.9\%), female (51.9\%), not married (66.1\%) and do not have children (87.9\%). Regarding the professional profile of the residents, we found that most of the students do more shifts to supplement their income (84.5\%), work up to an additional 24 hours (76.4\%), performed four or more night shifts in the last month (75.6\%) and works more than 60 hours per week (56.6\%).
About $80 \%$ of residents experienced a stressful event in the previous six months, $75 \%$ had adequate supervision at the medical residency, and the clinics hospital (HC) was the first place they chose to go (64.3\%). Most of the participants do not practice intense physical activity $(65.1 \%)$ and do drink alcohol (72.7\%). As for housing, $50.4 \%$ of the residents are from Recife and $72.9 \%$ do not live with their parents.

Burnout syndrome was found in 36 of the 129 residents through the MBI questionnaire, resulting in a prevalence of $27.9 \%$. As for the domains of burnout, the majority of the participants presented a high level of emotional exhaustion (59.7\%) and a low level of professional effectiveness (94.6\%). The level of depersonalization was high in $31.8 \%$ of the participants.

Table 1 compares residents who met criteria for burnout and those without the syndrome, illustrating the association with risk factors in the univariate analysis. Area

TABLE 1 Distribution of burnout syndrome according to the personal and professional profile of resident physicians at Hospital das Clínicas of Universidade Federal de Pernambuco.

\begin{tabular}{|c|c|c|c|}
\hline \multirow[t]{2}{*}{ Factor assessed } & \multicolumn{2}{|c|}{ Has burnout syndrome } & \multirow[t]{2}{*}{$\mathrm{p}$-value } \\
\hline & Yes & No & \\
\hline \multicolumn{4}{|l|}{ Year of residency } \\
\hline $1^{\text {st }}$ to $2^{\text {nd }}$ year & $23(26.4 \%)$ & $64(73.6 \%)$ & \multirow[t]{2}{*}{$0.59 *$} \\
\hline $3^{\text {rd }}$ to $5^{\text {th }}$ year & $13(31.0 \%)$ & $29(69.0 \%)$ & \\
\hline \multicolumn{4}{|l|}{ Age } \\
\hline Up to 28 years & $20(31.7 \%)$ & $43(68.3 \%)$ & \multirow[t]{2}{*}{$0.71 *$} \\
\hline Older than 28 years & $16(28.6 \%)$ & $40(71.4 \%)$ & \\
\hline \multicolumn{4}{|l|}{ Sex } \\
\hline Male & $17(27.4 \%)$ & $45(72.6 \%)$ & \multirow[t]{2}{*}{$0.90^{*}$} \\
\hline Female & $19(28.4 \%)$ & $48(71.6 \%)$ & \\
\hline \multicolumn{4}{|l|}{ Marital status } \\
\hline Not married & $25(29.8 \%)$ & $59(70.2 \%)$ & \multirow[t]{2}{*}{$0.62^{*}$} \\
\hline Married & $11(25.6 \%)$ & $32(74.4 \%)$ & \\
\hline \multicolumn{4}{|l|}{ Has children } \\
\hline Yes & $4(26.7 \%)$ & $11(73.3 \%)$ & \multirow[t]{2}{*}{$1.00 \dagger$} \\
\hline No & $31(28.4 \%)$ & $78(71.6 \%)$ & \\
\hline \multicolumn{4}{|l|}{ Specialization area } \\
\hline Surgical medicine & $16(44.4 \%)$ & $20(55.6 \%)$ & \multirow[t]{2}{*}{$0.01 *$} \\
\hline Other & $20(21.5 \%)$ & $73(78.5 \%)$ & \\
\hline \multicolumn{4}{|c|}{ Extra shifts to supplement income } \\
\hline Yes & $31(28.4 \%)$ & $78(71.6 \%)$ & \multirow[t]{2}{*}{$0.75^{*}$} \\
\hline No & $5(25.0 \%)$ & $15(75.0 \%)$ & \\
\hline \multicolumn{4}{|c|}{ Weekly hours of work } \\
\hline Up to 60 hours & $12(21.4 \%)$ & $44(78.6 \%)$ & \multirow[t]{2}{*}{$0.15^{*}$} \\
\hline More than 60 hours & $24(32.9 \%)$ & 49 (67.1\%) & \\
\hline
\end{tabular}


TABLE 1 (Cont.) Distribution of burnout syndrome according to the personal and professional profile of resident physicians at Hospital das Clínicas of Universidade Federal de Pernambuco.

\begin{tabular}{|c|c|c|c|}
\hline \multirow[t]{2}{*}{ Factor assessed } & \multicolumn{2}{|c|}{ Has burnout syndrome } & \multirow[t]{2}{*}{ p-value } \\
\hline & Yes & No & \\
\hline \multicolumn{4}{|c|}{ Stressful events in the previous 6 months } \\
\hline Yes & $35(33.7 \%)$ & $69(66.3 \%)$ & \multirow[t]{2}{*}{$<0.01^{*}$} \\
\hline No & $1(4.0 \%)$ & $24(96.0 \%)$ & \\
\hline \multicolumn{4}{|c|}{ Adequate supervision during residency } \\
\hline Yes & $24(25.0 \%)$ & $72(75.0 \%)$ & \multirow[t]{2}{*}{$0.17^{*}$} \\
\hline No & $12(37.5 \%)$ & $20(62.5 \%)$ & \\
\hline \multicolumn{4}{|l|}{ Regular physical activity } \\
\hline Yes & $9(20.0 \%)$ & $36(80.0 \%)$ & \multirow[t]{2}{*}{$0.14^{*}$} \\
\hline No & $27(32.1 \%)$ & $57(67.9 \%)$ & \\
\hline \multicolumn{4}{|l|}{ Use of alcoholic beverages } \\
\hline Yes & $29(31.2 \%)$ & $64(68.8 \%)$ & \multirow[t]{2}{*}{$0.21^{*}$} \\
\hline No & $7(20.0 \%)$ & $28(80.0 \%)$ & \\
\hline \multicolumn{4}{|l|}{ Place of origin } \\
\hline Greater Recife area & $21(32.3 \%)$ & $44(67.7 \%)$ & \multirow[t]{2}{*}{$0.26^{*}$} \\
\hline Other locations & $15(23.4 \%)$ & $49(76.6 \%)$ & \\
\hline \multicolumn{4}{|l|}{ Lives with } \\
\hline Parents & $14(40.0 \%)$ & $21(60.0 \%)$ & \multirow[t]{2}{*}{$0.06^{*}$} \\
\hline Other relatives, friends or alone & $22(23.4 \%)$ & $72(76.6 \%)$ & \\
\hline
\end{tabular}

* $p$-value of the Chi-square test for independence; $\uparrow p$-value of Fisher's exact test.

of specialization, stress event in the previous 6 months, supervision of residency, workload, physical activity and living with parents, friends or alone were the variables yielding $\mathrm{p}<0.2$ and thus submitted to multivariate analysis.

Table 2 shows the association between the resident profile and the MBI questionnaire domains. For the emotional exhaustion domain, the variables submitted to multivariate analysis due to $\mathrm{p}<0.2$ were specialization area, having children, performing supplementary shifts to increase income, stress event in the previous six months, supervision at the residency and place of origin. In the depersonalization domain, the variables submitted to multivariate analysis were area of specialization, stress event in the last six months, physical activity and living with parents, friends or alone. For the professional achievement domain, the variables were marital status, having children, stress event in the previous six months and use of alcoholic beverage.

Table 3 shows the final model with the factors that remained independently associated with $\mathrm{p}<0.05$. Burnout was about twice as prevalent in surgical residents (PR: 1.99; 95CI 1.20-3.29), and eight times more frequent in those who experienced stressful event in the previous six months (PR: 8.10; 95CI 1.15-57.16) after control for other covariates. These same factors were independently associated with high emotional exhaustion, while being in a surgical spe- cialty residency was the only factor that was associated with high depersonalization in the multivariate analysis. No factor was independently associated with low achievement.

\section{Discussion}

The prevalence of burnout in medical residency, according to the international literature, ranges from 27 to $75 \%$, depending on the specialty. ${ }^{13}$ Brazilian studies, on the other hand, reveal a prevalence between 20 and 50\%, using the same instrument adopted by us in this study: the MBI questionnaire. Half of the residents of internal medicine at a philanthropic hospital in São Paulo met the criteria for burnout in $2012 .{ }^{14}$ In a study performed in 2004 at Hospital de Clínicas of Universidade Federal de Uberlândia, the authors found a prevalence of $20.8 \%$ of burnout in residents from several specialties, ${ }^{9}$ similar to the figure found in 2009 at Hospital das Clínicas of Universidade Federal de Goiás, which was $18 \% .{ }^{6}$ A study with oncology residents only, from several centers in Brazil, identified a high prevalence of burnout (76\%). However, using as a criterion the presence of the three dimensions of the syndrome, this value drops to less than $36 \% .{ }^{15}$ Our study demonstrated a prevalence of $27.9 \%$ of burnout syndrome in HC-UFPE residents, which is compatible with the average of other studies conducted in Brazil. 
TABLE 2 Distribution of the emotional exhaustion, depersonalization and professional achievement domains, according to the personal and professional profile of resident physicians at Hospital das Clínicas of Universidade Federal de Pernambuco.

Factor assessed Emotional exhaustion

\begin{tabular}{|c|c|c|c|c|c|c|c|c|c|}
\hline & $\begin{array}{l}\text { Low/ } \\
\text { Moderate }\end{array}$ & High & p-value & $\begin{array}{l}\text { Low/ } \\
\text { Moderate }\end{array}$ & High & p-value & Low & Moderate & $\mathrm{p}$-value \\
\hline \multicolumn{10}{|l|}{ Year of residency } \\
\hline $1^{\text {st }}$ to $2^{\text {nd }}$ year & $33(37.9 \%)$ & $54(62.1 \%)$ & $0.43 *$ & $60(69.0 \%)$ & $27(31.0 \%)$ & $0.79 *$ & $82(94.3 \%)$ & $5(5.7 \%)$ & $1.00 \dagger$ \\
\hline $3^{\text {rd }}$ to $5^{\text {th }}$ year & $19(45.2 \%)$ & $23(54.8 \%)$ & & $28(66.7 \%)$ & $14(33.3 \%)$ & & $40(95.2 \%)$ & $2(4.8 \%)$ & \\
\hline \multicolumn{10}{|l|}{ Age } \\
\hline Up to 28 years & $23(36.5 \%)$ & $40(63.5 \%)$ & $0.27^{*}$ & $38(60.3 \%)$ & $25(39.7 \%)$ & $0.20^{*}$ & $61(96.8 \%)$ & $2(3.2 \%)$ & $0.25 \dagger$ \\
\hline Older than 28 years & $26(46.4 \%)$ & $30(53.6 \%)$ & & $40(71.4 \%)$ & $16(28.6 \%)$ & & $51(91.1 \%)$ & $5(8.9 \%)$ & \\
\hline \multicolumn{10}{|l|}{ Sex } \\
\hline Male & $28(45.2 \%)$ & $34(54.8 \%)$ & $0.28^{*}$ & $42(67.7 \%)$ & $20(32.3 \%)$ & $0.91 *$ & $57(91.9 \%)$ & $5(8.1 \%)$ & $0.26+$ \\
\hline Female & $24(35.8 \%)$ & $43(64.2 \%)$ & & $46(68.7 \%)$ & $21(31.3 \%)$ & & $65(97.0 \%)$ & $2(3.0 \%)$ & \\
\hline \multicolumn{10}{|l|}{ Marital status } \\
\hline Not married & $31(36.9 \%)$ & $53(63.1 \%)$ & $0.43 *$ & $55(65.5 \%)$ & $29(34.5 \%)$ & $0.45^{*}$ & $82(97.6 \%)$ & $2(2.4 \%)$ & $0.04 \dagger$ \\
\hline Married & $19(44.2 \%)$ & $24(55.8 \%)$ & & $31(72.1 \%)$ & $12(27.9 \%)$ & & $38(88.4 \%)$ & $5(11.6 \%)$ & \\
\hline \multicolumn{10}{|l|}{ Has children } \\
\hline Yes & $9(60.0 \%)$ & $6(40.0 \%)$ & $0.10^{*}$ & $10(66.7 \%)$ & $5(33.3 \%)$ & $1.00 *$ & $12(80.0 \%)$ & $3(20.0 \%)$ & $0.04 \dagger$ \\
\hline No & $41(37.6 \%)$ & $68(62.4 \%)$ & & $74(67.9 \%)$ & $35(32.1 \%)$ & & $105(96.3 \%)$ & $4(3.7 \%)$ & \\
\hline \multicolumn{10}{|l|}{ Specialization area } \\
\hline Surgical medicine & $9(25.0 \%)$ & $27(75.0 \%)$ & $0.03 *$ & $20(55.6 \%)$ & $16(44.4 \%)$ & $0.06^{*}$ & $34(94.4 \%)$ & $2(5.6 \%)$ & $1.00 \dagger$ \\
\hline Other & $43(46.2 \%)$ & $50(53.8 \%)$ & & $68(73.1 \%)$ & $25(26.9 \%)$ & & $88(94.6 \%)$ & $5(5.4 \%)$ & \\
\hline \multicolumn{10}{|c|}{ Extra shifts to supplement income } \\
\hline Yes & $41(37.6 \%)$ & $68(62.4 \%)$ & $0.14^{*}$ & $75(68.8 \%)$ & $34(31.2 \%)$ & $0.74 *$ & $103(94.5 \%)$ & $6(5.5 \%)$ & $1.00 \dagger$ \\
\hline No & $11(55.0 \%)$ & $9(45.0 \%)$ & & $13(65.0 \%)$ & $7(35.0 \%)$ & & $19(95.0 \%)$ & $1(5.0 \%)$ & \\
\hline \multicolumn{10}{|c|}{ Weekly hours of work } \\
\hline Up to 60 hours & $25(44.6 \%)$ & $31(55.4 \%)$ & $0.38^{*}$ & $41(73.2 \%)$ & $15(26.8 \%)$ & $0.29 *$ & $52(92.9 \%)$ & $4(7.1 \%)$ & $0.47 \dagger$ \\
\hline More than 60 hours & $27(37.0 \%)$ & $46(63.0 \%)$ & & $47(64.4 \%)$ & $26(35.6 \%)$ & & $70(95.9 \%)$ & $3(4.1 \%)$ & \\
\hline \multicolumn{10}{|c|}{ Stressful events in the previous 6 months } \\
\hline Yes & $31(29.8 \%)$ & $73(70.2 \%)$ & $<0.01 *$ & $66(63.5 \%)$ & $38(36.5 \%)$ & $0.02 *$ & $100(96.2 \%)$ & $4(3.8 \%)$ & $0.13 \dagger$ \\
\hline No & $21(84.0 \%)$ & $4(16.0 \%)$ & & $22(88.0 \%)$ & $3(12.0 \%)$ & & $22(88.0 \%)$ & $3(12.0 \%)$ & \\
\hline \multicolumn{10}{|c|}{ Adequate supervision during residency } \\
\hline Yes & $43(44.8 \%)$ & $53(55.2 \%)$ & $0.04^{*}$ & $68(70.8 \%)$ & $28(29.2 \%)$ & $0.23 *$ & $91(94.8 \%)$ & $5(5.2 \%)$ & $1.00+$ \\
\hline No & $8(25.0 \%)$ & $24(75.0 \%)$ & & $19(59.4 \%)$ & $13(40.6 \%)$ & & $30(93.8 \%)$ & $2(6.3 \%)$ & \\
\hline \multicolumn{10}{|c|}{ Regular physical activity } \\
\hline Yes & $20(44.4 \%)$ & $25(55.6 \%)$ & $0.48^{*}$ & $35(77.8 \%)$ & $10(22.2 \%)$ & $0.09 *$ & $41(91.1 \%)$ & $4(8.9 \%)$ & $0.24 \dagger$ \\
\hline No & $32(38.1 \%)$ & $52(61.9 \%)$ & & $53(63.1 \%)$ & $31(36.9 \%)$ & & $81(96.4 \%)$ & $3(3.6 \%)$ & \\
\hline \multicolumn{10}{|c|}{ Use of alcoholic beverages } \\
\hline Yes & $35(37.6 \%)$ & $58(62.4 \%)$ & $0.26^{*}$ & $61(65.6 \%)$ & $32(34.4 \%)$ & $0.35^{*}$ & $90(96.8 \%)$ & $3(3.2 \%)$ & $0.09+$ \\
\hline No & $17(48.6 \%)$ & $18(51.4 \%)$ & & $26(74.3 \%)$ & $9(25.7 \%)$ & & $31(88.6 \%)$ & $4(11.4 \%)$ & \\
\hline \multicolumn{10}{|l|}{ Place of origin } \\
\hline Greater Recife area & $21(32.3 \%)$ & $44(67.7 \%)$ & $0.06^{*}$ & $42(64.6 \%)$ & $23(35.4 \%)$ & $0.38^{*}$ & $63(96.9 \%)$ & $2(3.1 \%)$ & $0.27 \dagger$ \\
\hline Other locations & $31(48.4 \%)$ & $33(51.6 \%)$ & & $46(71.9 \%)$ & $18(28.1 \%)$ & & $59(92.2 \%)$ & $5(7.8 \%)$ & \\
\hline \multicolumn{10}{|l|}{ Lives with } \\
\hline Parents & $11(31.4 \%)$ & $24(68.6 \%)$ & $0.21 *$ & $20(57.1 \%)$ & $15(42.9 \%)$ & $0.10 *$ & $34(97.1 \%)$ & $1(2.9 \%)$ & $0.67 \dagger$ \\
\hline $\begin{array}{l}\text { Other relatives, friends } \\
\text { or alone }\end{array}$ & $41(43.6 \%)$ & $53(56.4 \%)$ & & $68(72.3 \%)$ & $26(27.7 \%)$ & & $88(93.6 \%)$ & $6(6.4 \%)$ & \\
\hline
\end{tabular}


TABLE 3 Multivariate analysis of burnout syndrome and associated factors in resident physicians at Hospital das Clínicas of Universidade Federal de Pernambuco.

\begin{tabular}{|c|c|c|c|c|}
\hline & Factor assessed & PR & $95 \mathrm{Cl}$ & p-value* \\
\hline \multirow[t]{6}{*}{ Burnout syndrome } & \multicolumn{4}{|l|}{ Specialty } \\
\hline & Surgical medicine & 1.99 & $1.20-3.29$ & 0.008 \\
\hline & Other & 1.00 & - & - \\
\hline & \multicolumn{4}{|l|}{ Stressful event in the previous 6 months } \\
\hline & Yes & 8.10 & $1.15-57.16$ & 0.036 \\
\hline & No & 1.00 & - & - \\
\hline \multirow[t]{6}{*}{ Emotional exhaustion } & \multicolumn{4}{|l|}{ Specialty } \\
\hline & Surgical medicine & 1.35 & $1.04-1.74$ & 0.022 \\
\hline & Other & 1.00 & - & - \\
\hline & \multicolumn{4}{|l|}{ Stressful event in the previous 6 months } \\
\hline & Yes & 4.32 & $1.78-10.46$ & 0.001 \\
\hline & No & 1.00 & - & - \\
\hline \multirow[t]{3}{*}{ Depersonalization } & \multicolumn{4}{|l|}{ Specialty } \\
\hline & Surgical medicine & 1.65 & $1.007-2.71$ & 0.047 \\
\hline & Other & 1.00 & - & - \\
\hline
\end{tabular}

PR: prevalence ratio; $95 \mathrm{Cl}$ : $95 \%$ confidence interval; * $\mathrm{p}$-value of the Wald test.

As for Brazilian studies including physicians after completion of residency, the prevalence of burnout is lower. A prevalence of $7.4 \%$ was found in 297 intensive care physicians in the city of Salvador. ${ }^{16}$ The prevalence was also low (5.1\%) among pediatricians and obstetricians/ gynecologists of a teaching hospital in Pernambuco. ${ }^{12}$ This difference in prevalence can be explained by the characteristics of residents and medical residency. Resident physicians, in addition to experiencing stressing factors that are inherent to the medical profession, are under the pressure of medical residency (training nature and educational structure) and face conflicts that are common to young professionals (seeking independence and autonomy, conflict between work and leisure). ${ }^{8}$ Comparing the level of psychological stress among resident and nonresident physicians of Brazilian university hospitals, greater vulnerability to work stress was demonstrated in residents..$^{17}$ In addition, they are less able to cope with stress and feel less confident in accomplishing their tasks.

Regarding the domains of burnout, the high prevalence of low level of professional achievement is worth noting in our work (94.6\%). This prevalence was much lower in other studies with physicians living in Brazil, ranging from 17.6 to $33.3 \% .6,9,15$ The exception was a study by Fabichak that found $70.8 \%$ of the residents with low level of professional achievement. ${ }^{14}$ In our study, this can be explained by the period of data collection at the end of a school year, between October and November. Nevertheless, the physical and managerial difficulties experi- enced in the Unified Health System also contribute to the feeling of low professional achievement. The current study was conducted in a hospital linked to the public health system, whose resident physicians performed a small strike with temporary cessation of care in the period prior to data collection, due to the lack of basic conditions for professional practice. This event may have influenced the low professional achievement observed in our study and reflects the interference of the work environment in the personal satisfaction of the professional. According to Malasch, the lack of professional effectiveness seems to emerge more clearly from the lack of relevant resources, while emotional exhaustion seems to emerge from the presence of work overload. ${ }^{2}$

In the multivariate analysis, burnout was associated with surgical specialties. Thus, the risk of residents associated with surgical specialties developing burnout was twice as high as the risk of residents of other specialties $(p=0.008)$. Previous studies have found that resident surgeons live under more stress than other medical professionals. ${ }^{18,19}$ A Mexican study found that burnout is more prevalent in residents who work over 80 hours per week, being statistically more frequent in those with surgical specialties. ${ }^{20}$ Justifications for the association between burnout and surgical specialties were not determined in our study. One possible explanation would be the fact that surgical medicine is an area that demands more workload and has more demanding instructors. The influence of supervisors' behavior on the prevalence of burnout 
is known, so that residents who perceive themselves unappreciated by their teams are at greater risk of developing this condition. ${ }^{21}$

Being a resident of surgical areas was also independently associated with greater emotional exhaustion and depersonalization. A study from Uberlândia also showed that residents belonging to surgical areas presented greater depersonalization than those belonging to clinical areas. ${ }^{9}$ Emotional exhaustion was recognized as a problem by surgical residents in South Korea, but directly explored in those programs. ${ }^{18}$ This shows that although residents perceive the difficulties, Medical Residency Committees and preceptors do not generally recognize the professionals' susceptibility to burnout.

The other factor associated with burnout in the multivariate analysis was having suffered a stress event in the previous six months. These individuals were eight times more likely to develop burnout compared to those who did not experience a stressful event $(\mathrm{p}=0.036)$. Stressful events affect the physician in training in a negative way and can cause burnout. ${ }^{22}$ Stressors inside and outside the scope of medicine are able to deplete the personal resources of residents. ${ }^{10}$ In a Canadian study, the main sources of stress were tests and evaluations (38.9\%), financial problems $(25.5 \%)$ and family problems $(7.4 \%){ }^{22}$ We were unable to identify which type of stress event was most common in our sample. Nevertheless, we found that the burnout domain most often implicated was emotional exhaustion.

It is important that residents who are vulnerable to developing burnout syndrome seek psychological counseling. Resident physicians sought the psychological assistance group of the University of São Paulo more in the first year and due to factors related to adaptive crises. ${ }^{23}$ Early identification of residents susceptible to burnout would be important in resolving this type of assistance. In addition, Pereira-Lima and Loureiro identified the presence of higher scores for social skills in residents without burnout and mental health problems. Since social skills such as communication, empathy and ability to work as a team can be learned, it is important to develop these skills during medical residency training in order to improve practice. ${ }^{24}$

\section{Conclusion}

The prevalence of burnout among resident physicians was $27.9 \%$, consistent with other Brazilian studies. Most residents showed a low level of professional achievement. There was a significant association between burnout syndrome and both the practice of surgical specialties and the occurrence of a stressor event in the previous six months. Characterizing the burnout syndrome in resident physicians can contribute to the elaboration and consolidation of preventive and therapeutic measures in this population.

\section{Resumo}

Fatores associados à síndrome de burnout em médicos residentes de um hospital universitário

Objetivo: Determinar a prevalência da síndrome de burnout entre médicos residentes de várias especialidades e avaliar os fatores associados.

Método: Foram aplicados o questionário Maslach Burnout Inventory e um questionário sócio-demográfico para avaliar fatores associados à síndrome. Burnout foi definido pela associação de alto desgaste emocional e despersonalização e baixa realização profissional. Análise multivariada foi realizada por meio do ajuste do modelo de Poisson com a identificação dos fatores de risco e calculadas as razões de prevalência (RP). Dos 250 médicos residentes cadastrados no Hospital das Clínicas de Pernambuco, 129 participaram do estudo.

Resultados: Nos três domínios que caracterizam a síndrome de burnout, encontramos um baixo nível de realização profissional em 94,6\% dos médicos residentes entrevistados, alto nível de despersonalização em 31,8\% e $59,7 \%$ com alto nível de desgaste emocional. A prevalência de burnout encontrada foi de $27,9 \%$. Ter sofrido evento estressante nos seis meses anteriores (RP: 8,10; IC 95\% 1,2-57,2) e cursar especialidade cirúrgica (RP: 1,99; IC $95 \% 1,2-3,3)$ estiveram associados de forma independente ao burnout.

Conclusão: A prevalência de burnout encontrada em médicos residentes está de acordo com estudos brasileiros prévios. Residentes de especialidades cirúrgicas e aqueles que sofreram evento estressor foram identificados como susceptíveis neste estudo. A identificação precoce dos fatores de risco é fundamental para a implementação de medidas preventivas para o não desenvolvimento da síndrome.

Palavras-chave: burnout, residência médica, educação médica.

\section{References}

1. Freudenberger HJ. Staff burnout. J Soc Issues. 1974; 30(1):159-65.

2. Maslach C, Schaufeli WB, Leiter MP. Job burnout. Annu Rev Psychol. 2001; 52:397-422.

3. Prins JT, Gazendam-Donofrio SM, Tubben BJ, van der Heijden FM, van de Wiel HB, Hoekstra-Weebers JE. Burnout in medical residents: a review. Med Educ. 2007; 41(8):788-800.

4. Trigo TR., Teng CT, Hallak JEC. Síndrome de burnout ou estafa profissional e os transtornos psiquiátricos. Rev Psiquiatr Clín. 2007; 34(5):223-33. 
5. Ruiz CO, Rios FL. El burnout o síndrome de estar quemado en los profesionales sanitarios: revisión y perspectivas. Int J Clin Health Psychol. 2004; 4(1):137-60

6. Soares LR, Lopes TMO, Silva MAO, Ribeiro MVA, Almeida Júnior MP, Silva RA, et al. Burnout e pensamentos suicidas em médicos residentes de hospital universitário. Rev Bras Educ Med. 2012; 36(1):77-82.

7. Thomas NK. Resident burnout. JAMA. 2004; 292(23):2880-9.

8. Martins LAN. Natureza e magnitude do estresse na residência médica. Rev Assoc Med Bras. 1998; 44(1):28-34

9. Lima FD, Buunk AP, Araújo MBJ, Chaves JGM, Muniz DLO, Queiroz LB. Síndrome de burnout em residentes da Universidade Federal de Uberlândia. Rev Bras Educ Med. 2007; 31(2):137-46.

10. Dyrbye L, Shanafelt T. A narrative review on burnout experienced by medical students and residents. Med Educ. 2016; 50(1):132-49.

11. Lautert L. O desgaste profissional do enfermeiro [tese]. Salamanca: Facultad de Psicologia, Universidade Pontifícia de Salamanca; 1995.

12. Lima RAS, de Souza AI, Galindo RH, Feliciano KVO. Vulnerabilidade ao burnout entre médicos de hospital público do Recife. Ciênc Saúde Coletiva. 2013; 18(4):1051-8.

13. Ishak WW, Lederer S, Mandili C, Nikravesh R, Seligman L, Vasa M, et al. Burnout during residency training: a literature review. J Grad Med Educ. 2009; 1(2):236-42.

14. Fabichak C, Junior JSS, Morrone LC. Síndrome de burnout em médicos residentes e preditores organizacionais do trabalho. Rev Bras Med Trab. 2014; 12(2):79-84

15. Cubero DI, Fumis RR, de Sá TH, Dettino A, Costa FO, Van Eyll BM, et al. Burnout in medical oncology fellows: a prospective multicenter cohort study in Brazilian institutions. J Cancer Educ. 2016; 31(3):582-7.
16. Tironi MOS, Sobrinho CLN, Barros DS, Reis EJ, Filho EDM, Almeida A, et al. Professional burnout syndrome among intensive care physicians in Salvador, Brazil. Rev Assoc Med Bras. 2009; 55(6):656-62.

17. Katsurayama M, Gomes NM, Becker MAD, Santos MC, Makimoto FH, Santana LLO, et al. Avaliação dos níveis de estresse psicológico em médicos residentes e não residentes de hospitais universitários. Psicol Hosp (São Paulo). 2011; 9(1):75-96.

18. Kang S, Jo HS, Boo YJ, Lee JS, Kim CS. Occupational stress and related factors among surgical residents in Korea. Ann Surg Treat Res. 2015; 89(5):268-74

19. Maher Z, Milner R, Cripe J, Gaughan J, Fish J, Goldberg AJ. Stress training for the surgical resident. Am J Surg. 2013; 205(2):169-74.

20. López-Morales A, González-Velázquez F, Morales-Guzmán MI, EspinozaMartínez CE. Síndrome de burnout en residentes con jornadas laborales prolongadas. Rev Med Inst Mex Seguro Soc. 2007; 45(3):233-42.

21. Prins JT1, Gazendam-Donofrio SM, Dillingh GS, van de Wiel HB, van der Heijden FM, Hoekstra-Weebers JE. The relationship between reciprocity and burnout in Dutch medical residents. Med Educ. 2008; 42(7):721-8.

22. Matheson KM, Barrett T, Landine J, McLuckie A, Soh NL, Walter G. Experiences of psychological distress and sources of stress and support during medical training: a survey of medical students. Acad Psychiatry. 2016; 40(1):63-8.

23. Souza EN, Gianini RJ, Azevedo Neto RS, Eluf-Neto J. Perfil do médico residente atendido no Grupo de Assistência Psicológica ao Aluno (GRAPAL) da Faculdade de Medicina da Universidade de São Paulo. Rev Assoc Med Bras. 2009; 55(6):684-91.

24. Pereira-Lima K, Loureiro SR. Burnout, anxiety, depression, and social skills in medical residents. Psychol Health Med. 2015; 20(3):353-62 